\section{LABORATORY INVESTIGATION OF COAL BOTTOM ASH MODIFIED WARM MIX ASPHALT}

Zulfiqar Ali Jattaka,b, Norhidayah Abdul Hassana*, Mohd Khairul Idham Mohd Satara, Ramadhansyah Putra Jayac, Mohd Rosli Hainin $^{c}$

aschool of Civil Engineering, Faculty of Engineering, Universiti Teknologi Malaysia, 81310 UTM Johor Bahru, Johor, Malaysia bDepartment of Civil Engineering Balochistan University of Engineering and Technology Khuzdar, Pakistan

'Department of Civil Engineering, College of Engineering, Universiti Malaysia Pahang, 26300 Gambang, Pahang, Malaysia
Article history

Received

27 December 2020

Received in revised form

13 April 2021

Accepted

20 April 2021

Published online

20 June 2021

*Corresponding author hnorhidayah@utm.my

\section{Gaphical abstract}

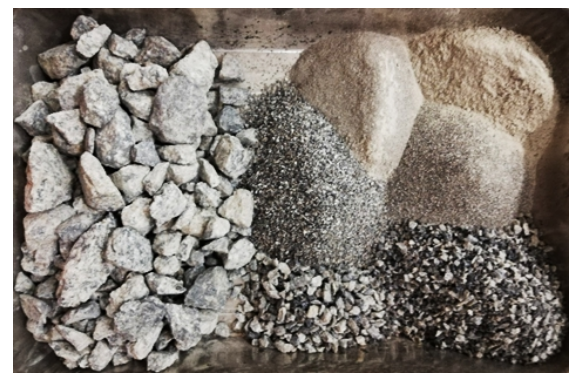

\begin{abstract}
Bottom Ash (BA), a coal combustion by-product, found to be a potential material when used to produce asphalt mixture. However, some of its characteristics make it a questionable material for the surface course. Therefore, this study aims to evaluate the compatibility of BA in Warm Mix Asphalt (WMA) technology through the basic mechanical properties of the asphalt mixtures for binder course layer (AC 28). Two WMA chemical additives, Cecabase RT and Evotherm 3G, were used at the concentrations of $0.3,0.4$ and $0.5 \%$ from the binder's weight. The binder properties were assessed through penetration, softening point and viscosity tests. The Marshall mix design was used to determine the optimum binder content (OBC). The additive dosage and production temperature for WMA were determined through Marshall stability, flow, air voids and specific gravity. The results show that the additives did not significantly affect the binder properties, although, at $0.4 \%$ Evotherm 3G, a drop of $17.5 \%$ in penetration was observed. Cecabase RT produced WMA with promising results but did not enhance the workability of WMA containing bottom ash (BAWMA). By lowering the production temperature of $25^{\circ} \mathrm{C}$, WMA and BAWMA at $0.4 \%$, Evotherm $3 G$ demonstrated comparable workability to the conventional Hot Mix Asphalt (HMA). The data achieved through this study would be a guiding approach towards the application of BA in WMA technology for sustainable pavements.
\end{abstract}

Keywords: Warm Mix Asphalt, bottom ash, chemical additives, compatibility, workability

\begin{abstract}
Abstrak
Abu Dasar (BA), produk sampingan pembakaran arang batu, didapati sebagai bahan berpotensi apabila digunakan untuk menghasilkan campuran asfalt. Walau bagaimanapun, beberapa ciri-ciri menjadikannya bahan yang meragukan untuk lapisan permukaan. Oleh itu, kajian ini bertujuan untuk menilai keserasian BA dalam teknologi Asfalt Campuran Suam (WMA) melalui ciri-ciri mekanikal asas campuran asfalt untuk lapisan pengikat (AC 28). Dua bahan tambahan kimia WMA, Cecabase RT dan Evotherm 3G, telah digunakan dengan $0.3,0.4$ dan $0.5 \%$ daripada berat pengikat. Ciri-ciri pengikat dinilai melalui ujian penembusan, titik lembut dan kelikatan. Reka bentuk campuran Marshall telah digunakan untuk menentukan kandungan pengikat optimum (OBC). Dos bahan tambah dan suhu penghasilan WMA ditentukan melalui kestabilan Marshall, aliran, lompang udara dan graviti tentu. Hasil kajian menunjukkan bahawa bahan tambah tidak mempengaruhi sifat pengikat secara signifikan, walaupun pada $0.4 \%$ Evotherm $3 G$,
\end{abstract}


penurunan $17.5 \%$ nilai penembusan telah diperhatikan. Cecabase RT telah menghasilkan WMA dengan keputusan yang memberangsangkan tetapi tidak meningkatkan kebolehkerjaan WMA yang mengandungi abu dasar (BAWMA). Dengan menurunkan suhu penghasilan sebanyak $25^{\circ} \mathrm{C}$, WMA dan BAWMA dengan $0.4 \%$ Evotherm $3 G$ menunjukkan kebolehkerjaan yang setanding dengan Asfalt Campuran Panas (HMA) konvensional. Data yang diperolehi melalui kajian ini akan menjadi panduan untuk penggunaan BA dalam teknologi WMA sebagai turapan lestari.

Kata kunci: Asfalt Campuran Suam, abu dasar, bahan tambah kimia, keserasian, kebolehkerjaan

(c) 2021 Penerbit UTM Press. All rights reserved

\subsection{INTRODUCTION}

In general, the production of Hot Mix Asphalt (HMA) requires considerable fuel and energy consumption, simultaneously generating greenhouse gases. The increase in the cost of energy and material coupled with environmental concerns has encouraged the design of cheaper asphalt pavements. From the perspective of economic and environmental benefits, new technology has been developed, generally referred to as Warm Mix Asphalt Technology (WMA). The design of WMA technology has resolved most of the concerns related to HMA. This technology was initially introduced in Europe in 1995 to provide environmental and economic benefits [1, 2]. According to NCHRP Report, 2011 WMA reduces production and compaction temperatures. Accordingly, less energy is used to produce WMA, resulting in lower emissions than HMA [3]. WMA helps to produce, place and compact asphalt mixtures at lower temperatures without compromising the quality of the end product [4-6]

WMA has been categorised into four types: water-based, water-bearing, organic/waxes and chemical additives [5-7]. Water-base and waterbearing techniques work on the same principle by introducing a small amount of water to the heated bitumen. This process causes a significant volume of foam that helps to coat the aggregates properly at reduced temperatures [8]. Waxes and fatty amides, including Sasobit, Asphaltan B and Licomont Bs, are known as organic additives. These types of additives can decrease the viscosity of asphalt binder at temperatures beyond its melting point. However, the chemical additives can be emulsifiers or surfactants that do not influence the bitumen viscosity but meant to reduce the internal friction between the binder and the aggregate $[3,8,9]$.

Cecabase RT is an oil-based chemical additive initially developed by CECA in 2006. It can be directly mixed with the binder at a rate of 0.2 to $0.5 \%$ by the binder weight. The producers claim that it allows approximately $40{ }^{\circ} \mathrm{C}$ reductions in production and compaction temperature of asphalt mixtures [10]. Despite this claim, limiting the ageing of the binder during the production of asphalt is useful. The higher asphalt mixture temperature results in higher oxidation. Lowering the temperature by the use of Cecabase RT reduces the ageing of the binder that prolongs the life of pavements [11].

Evotherm $3 G$ is a water-free additive that had been developed in Europe by Mead Westvaco and Eurovia since 2003 [12]. The developer has reported that this additive can reduce the production temperature by $50{ }^{\circ} \mathrm{C}$. This reduction in temperature is also claimed to offer $55 \%$ energy savings, approximately $45 \%$ reduction of $\mathrm{CO}_{2}$ and $\mathrm{SO}_{2}$ emissions, $60 \%$ reduction of $\mathrm{NO}_{x}, 41 \%$ reduction in organic materials and similar soluble fractions. Evotherm additives are in three varieties, including Evotherm ET (Emulsion Technology), Evotherm DAT (Dispersed Asphalt Technology) and Evotherm 3G (Third Generation) [10, 13]. The Evotherm 3G was released in 2008 and equipped with a stripping agent, providing resistance against moisture damage with a high tensile strength ratio [14].

Along with the enormous benefits of WMA technology, there are still some concerns related to its performance compared to HMA. Therefore, pavement experts and researchers are concerned not only with minimising the amount of energy used for the production of HMA but emphasising to achieve a comparable performance of this emerging technology [15]. In this context, its performance has been assessed through the different type of asphalt mixtures, like dense graded asphalt, crumb rubber modified asphalt and porous asphalt [16-18]. Despite this, its performance has widely been exercised using different aggregate types, recycled asphalt pavement and even with some industrial by-products like steel slag [6, 19-22]. This reveals that there is potential for further research to investigate the compatibility of similar reusable byproducts like Bottom Ash (BA) to enhance the environmental and economic benefits of this technology.

By contrast, industrial waste in the form of slags and ashes have been historically treated as solid wastes and dumped in landfills. The by-products termed coal combustion products (CCP), including fly ash (FA) and bottom ash (BA), are the primary industrial wastes generated from coal power plants 
during coal combustion. FA produced in the form of dust-like powder from the flue gases of furnaces after the coal is fired at $1100-1400{ }^{\circ} \mathrm{C}$, with the composition of spherical glassy particles. BA is comparatively more granular than FA and is deposited at the bottom of boilers after coal combustion [23].

Coal is the cheapest source of electricity generation in Malaysia, like other countries. According to the Energy Commission of Malaysia, Malaysian coal power plants, including the Tanjung Bin Power plant, contributed approximately $42.5 \%$ to the total electricity generation mix in 2016 [24]. Tanjung Bin Power Plant alone burns approximately 18,000 tons of coal every day to generate 2,100 MW of electricity, and the by-products generate due to this process is 180 and 1,620 tons of BA and FA per day. Similarly, the other power plants also generate tonnes of BA and FA. Ramzi Hannan et al. [25] noted that due to the contents of arsenic and heavy metals, BA is still considered waste materials in Malaysia. Therefore, BA is disposed of in landfills, silos and impoundment ponds. Massive dumping of BA in a limited space may pollute the surrounding soil and contaminate the underground and surface water [25].

In Europe, power plants produce over 19 million tons of BA every year. After the recovery of scrap metal and ageing for a specified time, the BA is used as gravel and sand in concrete and road construction. Denmark legislation declared BA a suitable material for road construction by recommending its use even for heavy loading roads in 2012. BA is also used in France, Germany, Belgium, Portugal, Spain and the United Kingdom as aggregate for road construction. More than $1 \mathrm{~km}$ of a noise barrier was built using BA along the A12 highway in the Netherlands. A total of 30,000 tons of BA was used in the backfill of the Stratford Olympic Village structure. Similarly, for the extension of a car parking, 5,000 tons of BA used as a sub-base material [26]. Since 1966, the American Coal Ash Association (ACAA) has conducted a survey yearly to estimate the production and the potential utilisation of coal combustion products. According to the ACAA report released on November 19, 2019, more than 102.3 million tons of coal ashes were produced in 2018 and over 59.4 million tons of beneficially used in different sectors. Consequently, in 2018, approximately 4.4 million tons BA was used in concrete products, blended cement, embankments, road bases and sub-bases, soil stabilisation and other similar purposes out of 9.2 million tons that were produced [27].

The latest research shows desirable engineering properties of BA without degrading the performance of asphalt mixtures by substituting a reliable portion of fine aggregate [28]. Several projects have already been completed using BA as an aggregate in asphalt concrete pavement layers. The asphalt mixture with BA requires a high percentage of binder content to satisfy Marshall mix design limits [29]. The effect of BA in asphalt mixtures has been thoroughly investigated through field and laboratory works. The asphalt mixture prepared by replacing the fine aggregate with $15 \%$ BA did not display significant degradation of tensile strength, low temperature cracking, or rutting potential compared with the conventional mixture but requires a higher percentage of binder content [30]. Hassan et al. [31] used up to $40 \%$ BA in HMA, replacing the fine aggregate by mass of the total mixture. Based on the dynamic modulus and rutting resistance results, they concluded that a maximum of $20 \%$ fine aggregate could be replaced with $B A$. Using a higher amount of $B A$ results in higher bitumen content and maximises the potential for permanent deformation. Byung Yoo et al. [32] ensured that using 10 to $30 \%$ BA by weight of the fine aggregate in the asphalt mixture did not significantly change the optimum binder content and the mixture properties. Chen et al. [33] recommended $20 \%$ and $10 \%$ BA for binder course and wearing course by the total mass of the mixture to achieve the required performance. The high abrasion value of BA increases ravelling potential. Therefore, Hassan [34] recommended the maximum use of $15 \%$ BA for the wearing course and $20 \%$ for the base course as fine aggregate replacement.

Bottom ash has been used in all pavement layers, including the wearing course, while minimal publications are available about its application in the binder course. BA has also been practised in cold mix asphalt, but there is a lack of literature investigating the effect of BA on the WMA mixtures using chemical additives. Therefore, based on the literature reviewed $[31,33,34]$ and BA's characteristics, $20 \%$ BA as fine aggregate by mass of the mixture in WMA for binder course was used. This study aims to encourage the recycling of $\mathrm{BA}$ generated from Malaysian power plants in WMA to design sustainable pavements. The main objective of this study is to examine the compatibility of WMA with BA by substituting a portion of fine aggregate. This attempt was exercised to produce a new asphalt mixture named Bottom Ash Warm Mix Asphalt (BAWMA).

\subsection{MATERIALS AND METHODOLOGY}

\subsection{Aggregate Characterisation}

The aggregates used in this study are granite and BA. The granite was collected from Hanson Heidelberg Cement Group, Kulai, Johor Bahru, and the BA was obtained from Tanjung Bin Power Plant Johor Bahru. The proportional distribution of aggregate and the combined gradation of coarse aggregate, fine aggregate and mineral filler for AC28 as demonstrated in Table 1, following the Public Works Department specification (JKR 2008).

The strength and durability of an asphalt mixture mainly depend on the properties of raw materials. Therefore, the properties of the materials were thoroughly investigated before the design of asphalt 
mixtures. Table 2 demonstrates the characterisation of granite and BA used in this study. Abrasion losses and the impact value of BA samples are much higher than those of granite aggregate, attributed to the porous structure and popcorn-like particles of BA. The high abrasion value of BA indicates a high potential for ravelling [34]. Therefore, BA has not been recommended as coarse aggregate in wearing course but as a fine aggregate by replacing a portion of the natural aggregate.

Table 1 Gradation limits of the combined aggregate for AC 28

\begin{tabular}{cccc}
\hline $\begin{array}{c}\text { Sieve } \\
\text { Size } \\
(\mathbf{m m})\end{array}$ & $\begin{array}{c}\text { \% Aggregate Retained by Weight } \\
\text { Conventional } \\
\text { Mix }\end{array}$ & $\begin{array}{c}\text { Mix with 20\% Bottom Ash } \\
\text { Granite }\end{array}$ & $\begin{array}{c}\text { Granite } \\
\text { Bottom Ash }\end{array}$ \\
\hline 28 & 0 & 0 & 0 \\
20 & 19 & 19 & 0 \\
14 & 14 & 14 & 0 \\
10 & 11 & 11 & 0 \\
5 & 17.5 & 17.5 & 0 \\
3.35 & 6.5 & 2.6 & 3.9 \\
1.18 & 11 & 4.4 & 6.6 \\
0.425 & 7 & 2.8 & 4.2 \\
0.150 & 7 & 2.8 & 4.2 \\
0.075 & 2 & 0.8 & 1.2 \\
Pan & 3 & 3 & \\
Hydrated & 2 & \multicolumn{3}{c}{0} \\
Lime & 2 & 2 \\
\hline
\end{tabular}

Table 2 Characterisation of the aggregates

\begin{tabular}{|c|c|c|c|c|}
\hline Testing & Standard & Granite & $\begin{array}{c}\text { Bottom } \\
\text { Ash }\end{array}$ & Specification \\
\hline LAAV & $\begin{array}{l}\text { ASTM } \\
\text { C131 }\end{array}$ & $16.0 \%$ & $49.1 \%$ & $\leq 25 \%$ \\
\hline AIV & $\begin{array}{l}\text { BS 812: } \\
\text { part } 112\end{array}$ & $15.8 \%$ & $38.8 \%$ & $<25 \%$ \\
\hline \multicolumn{5}{|c|}{ Specific Gravity: } \\
\hline $\begin{array}{l}\text { Coarse } \\
\text { Agg. }\end{array}$ & $\begin{array}{l}\text { AASHTO } \\
\text { T85 }\end{array}$ & 2.722 & 2.062 & - \\
\hline Fine Agg. & $\begin{array}{c}\text { AASHTO } \\
\text { T84 }\end{array}$ & 2.656 & 2.139 & - \\
\hline \multicolumn{5}{|c|}{ Water Absorption: } \\
\hline $\begin{array}{l}\text { Coarse } \\
\text { Agg. }\end{array}$ & $\begin{array}{c}\text { AASHTO } \\
\text { T85 }\end{array}$ & $0.5 \%$ & $1.1 \%$ & $\leq 2 \%$ \\
\hline Fine Agg. & $\begin{array}{c}\text { AASHTO } \\
\text { T84 }\end{array}$ & $0.5 \%$ & $1.6 \%$ & $\leq 2 \%$ \\
\hline $\begin{array}{l}\text { Sand } \\
\text { Equivalent }\end{array}$ & $\begin{array}{l}\text { ASTM } \\
\text { D2419 }\end{array}$ & $83.8 \%$ & $89.8 \%$ & Min. $45 \%$ \\
\hline $\begin{array}{l}\text { Agg. } \\
\text { Angularity }\end{array}$ & $\begin{array}{l}\text { ASTM } \\
\text { C1252 } \\
\end{array}$ & $45.7 \%$ & $56.5 \%$ & Min. $45 \%$ \\
\hline
\end{tabular}

The BA represented comparatively lower specific gravity and higher water absorption compared with the granite aggregate. Ramzi et al. [35] have reported similar results of specific gravity. The higher carbon content in BA may result in lower specific gravity [36]. Generally, BA represents lower specific gravity because of its porous or vesicular texture, indicating the presence of popcorn-like particles in the ashes. These particles tend to degrade under heavy loading and compaction [26].

\subsection{Binder and Chemical Additives Used}

In this research, 60/70 penetration grade bitumen and two chemical additives were used, namely, Cecabase RT and Evotherm 3G. The additive dosage was used for the trials at the rate of $0.3,0.4$ and $0.5 \%$ by weight of the total binder, based on the producers recommended range.

\subsection{Production of Modified Binders and Sample Preparation}

For the production of WMA binder, a required amount of virgin binder was heated to $130^{\circ} \mathrm{C}$ before adding the additives. Then, the additive was poured into the bitumen and thoroughly mixed using a mechanical mixer at $500 \mathrm{rpm}$ for 10 minutes to achieve a homogenous binder [11]. Three replicates were prepared for each percentage for the binder testing.

\subsection{Binder Characterisation}

The binders containing WMA additives were characterised to evaluate the blending compatibility and their basic properties, namely, penetration, softening point and viscosity [37]. The standard penetration test was performed based on ASTM D5/D5M-14. The test was conducted by applying a standard needle with the loading of $100 \mathrm{~g}$ to the bitumen filled in a cup at a temperature of $25^{\circ} \mathrm{C}$. The softening point of the samples was performed to measure their susceptibility to flow at elevated temperatures as per ASTM D36/D36M-14. The dynamic viscosity test was performed at different temperatures, including 100, 110, 120, 130, 140 and $160^{\circ} \mathrm{C}$ with different percentages $(0.3,0.4$ and $0.5 \%$ ) of each chemical additive. A rotational viscometer was used to measure the viscosity under ASTM D4402/D4402M-14.

\subsection{Type of Mixtures to Aggregate Composition}

On the basis of the preliminary investigation, four types of AC28 mixtures (conventional and modified) were proposed for this study enlisted in Table 3. 
Table 3 Composition of aggregate for each mixture type

\begin{tabular}{|c|c|c|}
\hline No & $\begin{array}{l}\text { Type of } \\
\text { Mixture }\end{array}$ & Aggregate Composition \\
\hline 1 & HMA & $\begin{array}{l}\text { Granite as coarse and fine aggregate } \\
+2 \% \text { hydrated lime (control) }\end{array}$ \\
\hline 2 & WMA & Granite as coarse and fine aggregate \\
\hline 3 & BAHMA & $\begin{array}{l}\text { Granite as coarse aggregate }+ \text { granite } \\
\text { as fine aggregate }+ \text { BA as fine } \\
\text { aggregate }+2 \% \text { hydrated lime }\end{array}$ \\
\hline 4 & BAWMA & $\begin{array}{l}\text { Granite as coarse aggregate }+ \text { granite } \\
\text { as fine aggregate }+ \text { BA as fine } \\
\text { aggregate }\end{array}$ \\
\hline
\end{tabular}

The intention was to replace the granite aggregate with a reliable proportion of $\mathrm{BA}$ for the design of Bottom Ash Hot Mix Asphalt (BAHMA) and BAWMA. The target is to promote the utilisation of BA without compromising the performance, strength and durability of the asphalt mixtures.

\subsection{Marshall Mix Design}

On the basis of the recommendation by the Public Works Department of Malaysia (JKR 2008) specification [38], the Marshall mix design was adopted to determine the optimum bitumen content (OBC) of the mixtures. The tests were conducted following the ASTM D2726/D2726M-13 and D6927-06 standards. The blended aggregate and the binder were heated at a temperature of $165^{\circ} \mathrm{C}$ and thoroughly mixed. Three replicates were prepared for each bitumen content ranging from 3.5 to $5.5 \%$ and compacted with 75 blows using a Marshall compactor simulating the design of flexible pavement for heavy traffic (greater than 106 ESALs) in accordance with ASTM D6926-10. The compacted samples were then evaluated for volumetric properties, flow and stability based on the criteria specified by the JKR (2008) specification.

\subsection{Optimum Dosage and Production Temperature}

Surfactant additives do not influence the viscosity of binders but reduce the surface tension at the aggregate interface to improve the workability of mixtures even at lower temperatures. The determination of the dosage and the production temperature of WMA through laboratory tests are the most critical part of any study [39]. No relevant standard testing procedure is available for the workability of WMA technologies. However, different techniques were applied to evaluate the effect of additives on the workability of asphalt mixtures [3941].

In this study, the effect of chemical additives on the asphalt mixtures was evaluated using the Marshall mix design method, using a range of additive percentages at lower temperatures. In order to determine an optimum dosage of additive and production temperature for the WMA mixtures, samples were prepared with $0.3,0.4$ and $0.5 \%$ additive by the weight of the total binder. The WMA samples were mixed at temperatures of 130 and $140{ }^{\circ} \mathrm{C}$ for 3 mins to attain $100 \%$ coating of the aggregates.

Finally, the optimum dosage and the mixing temperature for the WMA fabrication were obtained through the asphalt mixtures mechanical properties, including the targeted air voids, Marshall Stability, flow and specific gravity. A total of 90 samples were fabricated and tested, with three replicates for each mixture and composition of the additive. Thus, the workability and the influence of additives on the WMA and BAWMA mixtures produced at reduced temperatures were validated. The WMA samples were compacted at 120 and $130{ }^{\circ} \mathrm{C}, 10^{\circ} \mathrm{C}$ lower than the production temperature. The temperature reduction of mixtures could influence the viscosity of the asphalt binder and affect the air voids. Therefore, to avoid the typical temperature drop during compaction, the WMA specimens compaction temperature was maintained using a forced draft oven for two hours. The Marshall flow and stability of the specimens were determined at $60^{\circ} \mathrm{C}$ following the ASTM D6927-06 standard.

\subsection{RESULTS AND DISCUSSION}

\subsection{Binder Characterisation}

Table 4 shows that the addition of Cecabase RT additive up to $0.5 \%$ did not provide a significant change in the penetration values of $60 / 70$ bitumen. The results conformed with Silva et al. [42], where they did not observe any changes in the values of penetration and softening point using Cecabase RT. By contrast, a reduction in penetration was observed when Evotherm $3 G$ was used to modify the base bitumen with $0.3,0.4$ and $0.5 \%$. However, the softening point of the modified binders was slightly increased up to $3.5 \%$ with the addition of $0.3 \%$ Cecabase RT and $0.4 \%$ Evotherm. A similar drop in the penetration values and a minor increment of the softening point was observed in Vahora and Mishra [43] when they investigated the properties of binder modified with similar percentages of Evotherm $\mathrm{Jl}$. Thus, the results confirm that Cecabase RT does not significantly influence the properties of the binders. However, Evotherm $3 G$ influenced the binder by increasing its hardness by approximately $17.5 \%$. Table 4 shows that the modification of the 60/70 binder with chemical additives did not show any major increment or decrement in the Penetration Index (PI), even with a higher percentage of additives. The drop in PI value denotes higher temperature susceptibility and the increment of the values indicates lower temperature susceptibility [44].

On the basis of viscosity limitations $10.17 \pm 0.02$ and $0.28 \pm 0.03$ Pa.s) recommended by JKR and following ASTM D2493/D2493M-09 standard chart, the 
mixing and compaction temperatures for HMA were achieved as 164 and $152.5^{\circ} \mathrm{C}$, respectively, as shown in Figure 1. The addition of Cecabase RT and Evotherm 3G did not reduce mixtures' viscosity compared to the base bitumen. From the graphs shown in Figures 2 and 3 , a slight deflection of trendlines can be observed with a higher dosage of additives at lower temperatures. However, at $160^{\circ} \mathrm{C}$, their trendlines joined the trendline of the control samples. A similar trend was reported by Gonzalez et al. [39] and Silva et al. [42] when they evaluated Cecabase RT for their research works. Dai Xuan and Saleh [45] observed similar viscosity values when using $0.5 \%$ Evotherm $3 G$ in a laboratory study. Both additives showed a maximum reduction of (0.3 Pa.s) in viscosity. However, this reduction is not considered significant to enhance the workability of mixtures.

The results confirm that the chemical-based WMA additives have not been meant to reduce binders viscosity but to improve the workability of the asphalt mixtures. These additives act as surfaceactive agents used to enhance asphalt mixtures workability at reduced temperatures [42]. Surfaceactive agents are mainly designed to decrease the friction between aggregate and the binder by enhancing aggregate coating [8]. The chemical WMA additives are surfactant molecules used to change the interfacial interaction in different phases between the binder and aggregate. A small amount of chemical additive helps to coats the aggregates without changing the viscosity and the mechanical properties of the binder [39]. The viscoelastic behaviour of the bitumen highly influences friction between the interfaces of the binder and the aggregates. At lower temperatures, the friction is very high and resists the mixtures mixing and compaction ability. However, at elevated temperatures, the friction is reduced and the mixture becomes more workable during the compaction process. Thus, the HMA mixtures are handled relatively at elevated temperatures. Therefore, the optimum additive content and the production temperature of WMA mixtures were determined based on the mechanical properties of the asphalt mixtures in order to reduce the friction forces to a certain extent to ease the mixing and compaction of WMA at reduced temperatures.

Table 4 Characterisation of the binder with and without chemical additives

\begin{tabular}{|c|c|c|c|c|c|c|c|c|c|}
\hline Bitumen & Additive Type & Additive(\%) & Pen (dmm) & $\Delta_{\text {pen }}(\mathrm{dmm})$ & $\Delta_{\text {pen }}(\%)$ & $R \& B\left({ }^{\circ} \mathrm{C}\right)$ & $\Delta_{\mathrm{R} \& \mathrm{~B}}\left({ }^{\circ} \mathrm{C}\right)$ & $\Delta_{\mathrm{R} \& \mathrm{~B}}(\%)$ & PI \\
\hline \multirow{7}{*}{$60 / 70$} & \multirow[t]{2}{*}{ None } & 0 & 65.5 & 0.0 & 0.0 & 49.25 & 0.0 & 0.0 & -0.75 \\
\hline & & 0.3 & 64.1 & -1.4 & -2.1 & 51 & 1.75 & 3.6 & -0.35 \\
\hline & \multirow[t]{3}{*}{ Cecabase RT } & 0.4 & 65.70 & 0.2 & 0.3 & 49 & -0.25 & 0.5 & -0.81 \\
\hline & & 0.5 & 62.62 & -2.88 & -4.4 & 48.25 & -1.0 & 2.0 & -1.13 \\
\hline & & 0.3 & 56.2 & -9.3 & -14.2 & 50.25 & 1 & 2.0 & -0.94 \\
\hline & \multirow[t]{2}{*}{ Evotherm 3G } & 0.4 & 55.6 & -9.9 & -17.5 & 51 & 1.75 & 3.6 & -0.80 \\
\hline & & 0.5 & 63.2 & -2.3 & -3.5 & 50 & 0.75 & 1.5 & -0.81 \\
\hline
\end{tabular}

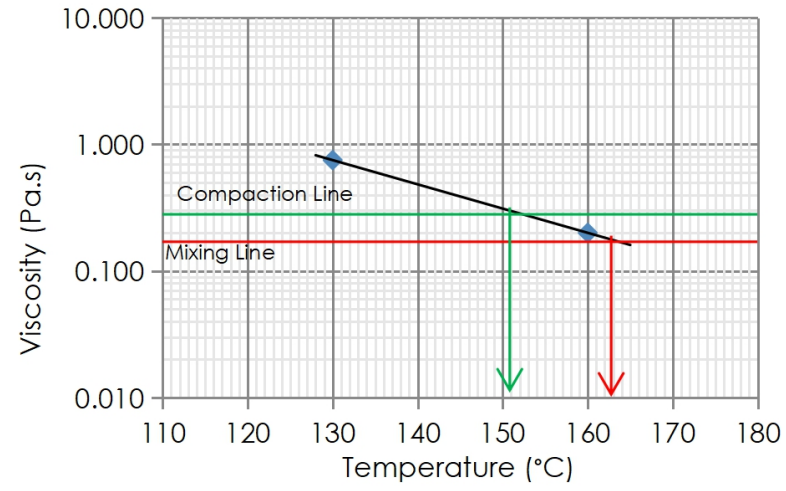

Figure 1 Mixing and compaction temperature for HMA

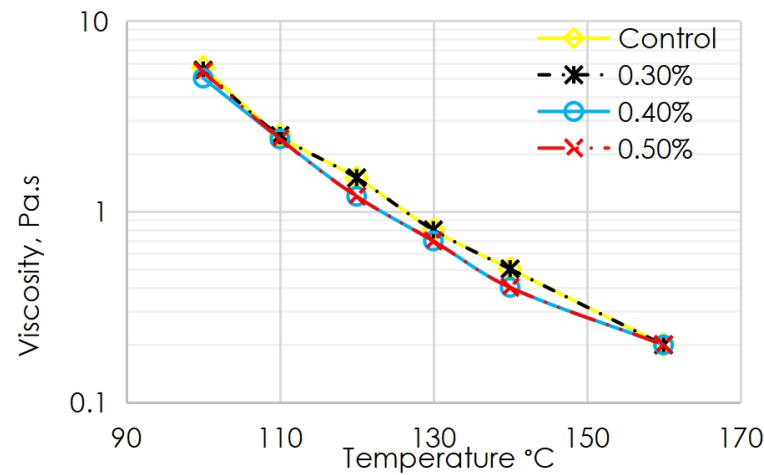

Figure 2 Viscosity of binder modified with Cecabase RT 


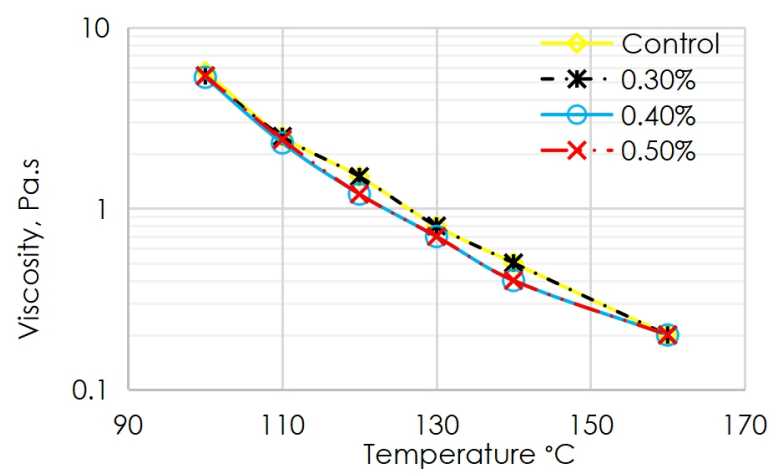

Figure 3 Viscosity of binder modified with Evotherm 3G

\subsection{Marshall Mix Design}

Table 5 demonstrates the resultant $\mathrm{OBC}$ based on the properties of the mixtures investigated. The OBC of both (control and BAHMA) mixtures was computed based on maximum Marshall stability, Voids Filled with Binder (VFB), Voids in Total Mix (VTM) and peak specific gravity of the mixtures.

The mixture prepared with $20 \%$ BA demonstrated a slight decrease in stability than the control mixture. A possible reason for this result is the lower specific gravity and the lower strength of BA. However, the obtained value is greater than the stability $(8000 \mathrm{~N})$ threshold set by the JKR (2008) specification. The resultant stability of BAHMA indicates that the mixture can safely withstand traffic loading if properly designed. The specific gravity of the mixture containing BA was also dropped down compared with the control mixture.

The asphalt mixture air voids is also a significant parameter in the permanent deformation and durability of a pavement layer. The BAHMA showed higher air voids even at a higher binder content. The possible reason for this result is the absorptive nature of BA. The mixture containing BA requires additional binder content to limit the air voids within the designated range. A similar trend was observed in VFB; the targeted VFB of BAHMA was achieved relatively at a higher binder content than the control mixture.

The OBC of both types of mixtures was computed based on the criteria, including Marshall stability, voids in total mix, voids filled with the binder and the bulk specific gravity of the asphalt mixtures. Following the Marshall mix design criteria, the OBC of control and BAHMA was obtained as 4.2 and $4.8 \%$, respectively. The mixture with $20 \%$ BA demonstrated an increment of $0.6 \%$ in binder content. The increment of binder content is because of the surface texture, the internal porosity and deep cavities of BA [46]. This property increases the surface area of particles by making it highly absorptive compared with natural aggregates. A similar increase in binder content was observed when Yoo et al. [32] and Colonna et al. [47] investigated mixtures containing BA.

As shown in Table 5, the results BA can potentially be substituted as a part of fine aggregate in the production of asphalt mixtures. As can be observed that all the mechanical properties of asphalt mixture containing 20\% BA satisfy the Marshall mix design criteria at the optimum binder content of $4.8 \%$.

Table 5 Marshall properties and OBC of the control mixture and BAHMA

\begin{tabular}{lccc}
\hline Properties & Criteria & Control & $\begin{array}{c}\text { Bottom } \\
\text { Ash }\end{array}$ \\
\hline BA Content, \% & - & 0 & 20 \\
Marshall Stability, N & $>8000$ & 18534 & 16596 \\
$\begin{array}{l}\text { Bulk Specific } \\
\text { Gravity }\end{array}$ & - & 2.450 & 2.335 \\
$\begin{array}{l}\text { Voids Content } \\
\text { (VTM), \% }\end{array}$ & $3.0-7.0$ & 3.5 & 5 \\
$\begin{array}{l}\text { Voids filled with } \\
\text { Bitumen (VFB), \% }\end{array}$ & $65-75$ & 73 & 68 \\
$\begin{array}{l}\text { Flow, mm } \\
\text { Stiffness, N/mm }\end{array}$ & $2.0-4.0$ & 3.6 & 3.2 \\
$\begin{array}{l}\text { Optimum Binder } \\
\text { Content (OBC), \% }\end{array}$ & 3.55 .5 & 4900 & 4950 \\
& & & 4.8 \\
\hline
\end{tabular}

\subsection{Optimum Additive Dosage and Production Temperature}

Since the surfactants do not change the binder properties, as observed in the preliminary results demonstrated in Table 4 and Figures 2 and 3. Therefore, additives impact was investigated through the mechanical properties of the asphalt mixtures produced with $0.3,0.4$ and $0.5 \%$ additives at 130 and $140{ }^{\circ} \mathrm{C}$. The results achieved from WMA mixtures mechanical properties were compared with the reference asphalt mixtures (prepared at lower temperatures without additives) and the conventional HMA. The impact of additives and temperature on compacted specimens with and without BA are tabulated in Tables 6 and graphically presented in Figures 4 to 7 .

Figures 4 and 5 compare the WMA mixtures with conventional and the reference asphalt mixtures. The mechanical properties of the reference asphalt mixtures were highly affected when produced at 130 and $140^{\circ} \mathrm{C}$. A reasonable reduction in Marshall stability and the bulk specific gravity of the mixtures can be observed. Similarly, an increase in air voids and the flow of the mixtures can be observed compared to the conventional mixture produced at $165^{\circ} \mathrm{C}$. A comparison was made for the mixtures Marshall stability evaluated using a range of additive contents and two different compaction temperatures. As displayed in Figures 4 and 5, WMA produced with different percentages of Evotherm $3 G$ at 140 and $130{ }^{\circ} \mathrm{C}$ showed a reasonable difference in Marshall stability results. Comparatively, the WMA mixtures produced with $0.4 \%$ Evotherm $3 G$ at $140{ }^{\circ} \mathrm{C}$ demonstrated greater stability than the reference WMA mixtures produced at $140^{\circ} \mathrm{C}$, but significantly lower stability than the control mixture produced at $165^{\circ} \mathrm{C}$. However, the Cecabase RT showed higher 
stability results at the production temperature of $140^{\circ} \mathrm{C}$ compared with the reference WMA mixture and the mixtures produced with Evotherm 3G. The $0.3 \%$ Cecabase RT demonstrated the highest stability, but it was slightly lower than the stability provided by the conventional HMA. The WMA mixtures produced at 130 and $140^{\circ} \mathrm{C}$ with different percentages of additives demonstrated a variable percentage of air voids. WMA mixtures produced with Evotherm $3 G$ slightly increase the air voids with a decrease in temperature. However, comparable results were achieved with higher additive content. The WMA mixtures produced at $140{ }^{\circ} \mathrm{C}$ using 0.4 and $0.5 \%$ Evotherm $3 \mathrm{G}$ produced almost similar air voids to the conventional HMA, but at $130{ }^{\circ} \mathrm{C}$, the air voids increased to a certain extent. By contrast, the use of $0.3 \%$ Cecabase RT showed comparable results at a temperature of $140{ }^{\circ} \mathrm{C}$, where an increase in additive tends to increase the air voids.

For the flow values, in the case of WMA mixtures produced with additives, samples with Evotherm $3 G$ demonstrated superior results. A production temperature of $140^{\circ} \mathrm{C}$ with $0.5 \%$ Evotherm $3 \mathrm{G}$ provides the least flow value compared to other mixtures. The small variation of temperature does not seem to influence the flow values for WMA containing Evotherm 3G. By contrast, a gradual increase was observed in the flow values of WMA mixtures with Cecabase RT. The least flow value was obtained at $0.3 \%$ Cecabase RT, which is comparable to the conventional HMA flow. The decrease in production temperature from $140^{\circ} \mathrm{C}$ to $130^{\circ} \mathrm{C}$ seems to increase the flow values of mixtures containing Cecabase RT.

A reasonable drop can be observed (Figures 6 and 7) in the stability results provided by the BAWMA mixtures. By contrast, both reference BAWMA mixtures produced at 140 and $130{ }^{\circ} \mathrm{C}$ did not show any difference in the stability results. Thus, the temperature difference of $10^{\circ} \mathrm{C}$ does not influence the stability of mixtures prepared with BA. The additives considerably influenced the BAWMA mixtures. In the case of corresponding WMA mixtures, the Cecabase RT additive demonstrated much better results but did not perform well when applied to the asphalt mixtures containing BA. In the case of BAWMA mixtures, Evotherm $3 G$ demonstrated comparatively better stability results at the production temperature of $140^{\circ} \mathrm{C}$. As compared with the reference BAWMA mixtures and the mixtures produced with Cecabase RT at $140^{\circ} \mathrm{C}$, the $0.4 \%$ Evotherm $3 G$ showed the highest stability. By contrast, Cecabase RT demonstrated the lowest stability results when used to produce BAWMA mixtures at reduced temperatures. Stability values demonstrated by the use of Cecabase RT are even lower than the results produced by the reference BAWMA mixtures at both production temperatures. This finding indicates that Cecabase RT is not compatible with the mixtures containing BA. The behaviour of asphalt mixtures showed that different surfactants act differently with different materials and are not necessarily compatible with every type of aggregate used.

As expected, the BAWMA mixtures with both additives demonstrated higher air voids compared with the control and BAHMA mixtures. High variability in the air voids of the mixtures can be observed in Figures 6 and 7. Specimens containing Cecabase RT showed higher air voids compared with those with Evotherm $3 \mathrm{G}$ even at the production temperature of $140{ }^{\circ} \mathrm{C}$. Mixtures with Evotherm $3 G$ demonstrated reasonable air voids. The lowest air void presented by $0.4 \%$ Evotherm $3 G$ is comparable to the results obtained from the BAHMA mixture produced at $165^{\circ} \mathrm{C}$. The high air voids content demonstrated by BAWMA mixtures could be due to the high internal friction and porosity of BA, providing a larger surface area within the mixture.

Table 6 Mechanical properties of WMA and BAWMA mixtures using Cecabase RT

\begin{tabular}{|c|c|c|c|c|c|c|c|c|}
\hline \multicolumn{2}{|c|}{ Type of Mixture } & $\begin{array}{l}\text { Type of } \\
\text { Additive }\end{array}$ & $\begin{array}{c}\text { Additive } \\
\text { (\%) }\end{array}$ & $\begin{array}{c}\text { Mixing } \\
\text { Temperature } \\
\left({ }^{\circ} \mathrm{C}\right)\end{array}$ & $\begin{array}{l}\text { Marshall } \\
\text { Stability } \\
\text { (N) }\end{array}$ & $\begin{array}{c}\text { Air Voids } \\
(\%)\end{array}$ & Specific Gravity & $\begin{array}{l}\text { Flow } \\
(\mathrm{mm})\end{array}$ \\
\hline \multicolumn{2}{|c|}{ HMA (Control) } & \multirow{6}{*}{ N/A } & \multirow{6}{*}{0} & \multirow{2}{*}{165} & 17,980 & 3.5 & 2.458 & 3.52 \\
\hline BAHMA & & & & & 16,317 & 5.3 & 2.315 & 3.24 \\
\hline \multirow{4}{*}{$\begin{array}{l}\text { Reference } \\
\text { WMA } \\
\text { mixtures }\end{array}$} & WMA & & & 140 & 14,185 & 3.9 & 2.446 & 4.23 \\
\hline & WMA & & & 130 & 12,607 & 4.6 & 2.439 & 4.65 \\
\hline & BAWMA & & & 140 & 11,594 & 6.3 & 2.292 & 3.47 \\
\hline & BAWMA & & & 130 & 11,611 & 6.9 & 2.277 & 4.38 \\
\hline \multirow{6}{*}{ WMA } & \multirow{6}{*}{ WMA } & \multirow{6}{*}{$\begin{array}{c}\text { Cecabase } \\
\text { RT }\end{array}$} & 0.3 & & 15,437 & 3.6 & 2.455 & 3.59 \\
\hline & & & 0.4 & 140 & 14,416 & 3.8 & 2.450 & 3.84 \\
\hline & & & 0.5 & & 15,174 & 4.4 & 2.435 & 3.92 \\
\hline & & & 0.3 & & 14,069 & 4.3 & 2.437 & 3.92 \\
\hline & & & 0.4 & 130 & 13,660 & 4.4 & 2.434 & 4.34 \\
\hline & & & 0.5 & & 13,611 & 4.9 & 2.421 & 4.48 \\
\hline
\end{tabular}




\begin{tabular}{|c|c|c|c|c|c|c|c|c|}
\hline \multirow{6}{*}{\multicolumn{2}{|c|}{ BAWMA }} & & 0.3 & \multirow{3}{*}{140} & 11,151 & 6.8 & 2.279 & 3.65 \\
\hline & & & 0.4 & & 10,876 & 7.0 & 2.275 & 3.94 \\
\hline & & & 0.5 & & 11,359 & 6.9 & 2.278 & 3.91 \\
\hline & & & 0.3 & \multirow{3}{*}{130} & 10,557 & 6.8 & 2.280 & 3.83 \\
\hline & & & 0.4 & & 10,814 & 7.2 & 2.268 & 3.95 \\
\hline & & \multirow{13}{*}{$\begin{array}{c}\text { Evotherm } \\
\quad 3 G\end{array}$} & 0.5 & & 10,443 & 7.2 & 2.271 & 3.97 \\
\hline \multirow{12}{*}{ WMA } & \multirow{7}{*}{ WMA } & & 0.3 & & 14,195 & 3.8 & 2.451 & 3.56 \\
\hline & & & 0.4 & 140 & 14,903 & 3.6 & 2.456 & 3.38 \\
\hline & & & 0.5 & & 14,203 & 3.6 & 2.454 & 3.30 \\
\hline & & & 0.3 & & 12,742 & 4.4 & 2.436 & 3.50 \\
\hline & & & 0.4 & 130 & 13,209 & 4.5 & 2.432 & 3.44 \\
\hline & & & 0.5 & & 12,939 & 4.0 & 2.444 & 3.40 \\
\hline & & & 0.3 & \multirow{3}{*}{140} & 12,342 & 6.0 & 2.298 & 2.90 \\
\hline & \multirow{5}{*}{ BAWMA } & & 0.4 & & 12,916 & 5.6 & 2.309 & 2.79 \\
\hline & & & 0.5 & & 12,655 & 5.9 & 2.302 & 2.82 \\
\hline & & & 0.3 & \multirow{3}{*}{130} & 11,826 & 6.7 & 2.281 & 3.17 \\
\hline & & & 0.4 & & 12,128 & 6.6 & 2.285 & 3.02 \\
\hline & & & 0.5 & & 12,004 & 6.7 & 2.282 & 3.03 \\
\hline
\end{tabular}

As shown in Figures 6 and 7 , the BAWMA mixtures demonstrated the lowest flow values compared to the conventional HMA, BAHMA and the reference WMA mixtures. The most effective percentage of Evotherm $3 \mathrm{G}$ remained at $0.4 \%$, providing $2.79 \mathrm{~mm}$ of flow at $140{ }^{\circ} \mathrm{C}$ production temperature. It has been observed that the Evotherm 3G coupled with BA positively influenced the flow of the asphalt mixture. Likewise, Cecabase RT showed comparatively higher than did the results demonstrated by Evotherm 3G. In the case of flow, the Evotherm $3 G$ demonstrated reliable compatibility with the combination of granite and BA.

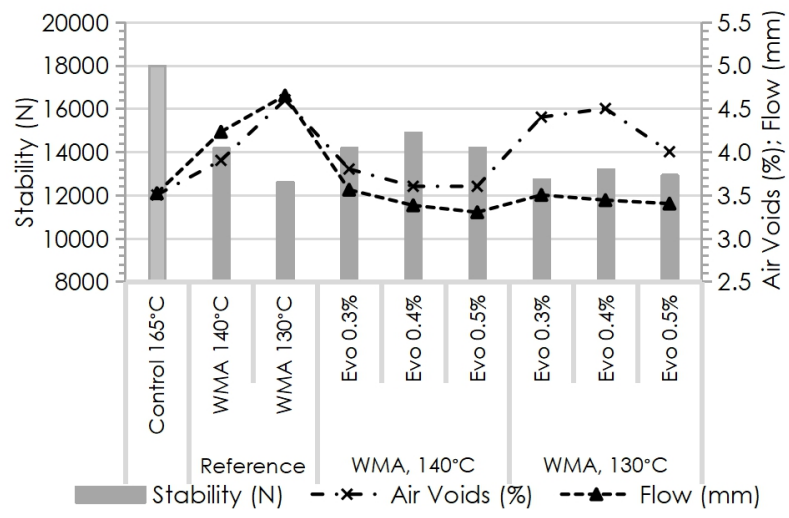

Figure 4 Influence of Evotherm $3 G$ on the stability, air voids and flow of the WMA mixtures

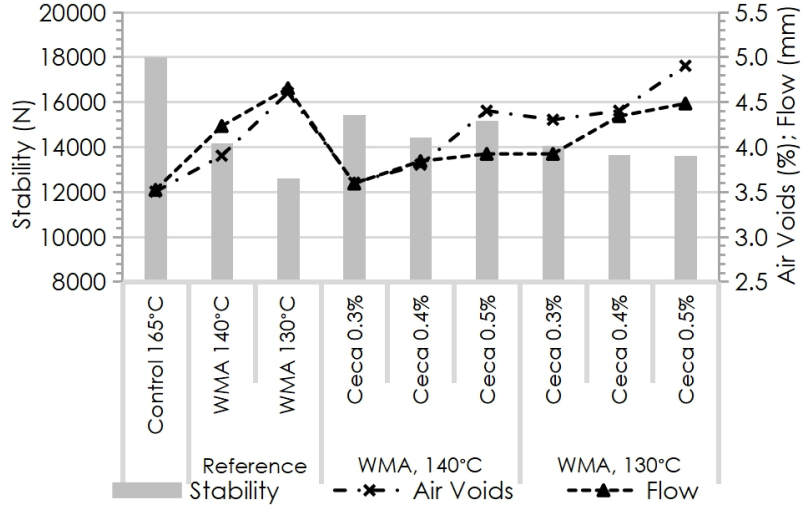

Figure 5 Influence of Cecabase RT on the stability, air voids and flow of the WMA mixtures.

\subsection{CONCLUSION}

This study evaluated the compatibility of chemical additives to produce WMA mixtures containing BA through Marshall and volumetric properties of the mixtures. The basic characterisation of BA satisfies the standard specifications as a fine aggregate. However, the abrasion loss and the greater impact value make it unacceptable material for wearing course. Lower specific gravity and higher water absorption of BA leads to higher bitumen content. A higher value of sand equivalent presented by BA indicates a lower amount of dust particles. The higher angularity of BA may increase the interlocking and help to resist 
permanent deformation. Cecabase RT insignificantly influenced the binder penetration grade. However, Evotherm $3 G$ reduced the binder penetration value by about $17.5 \%$ with $0.4 \%$ additive, while at the dosage of $0.5 \%$, the difference was insignificant. Both additives did not alter the viscosity of the bitumen. The BA modified asphalt mixtures significantly reduced the stability and increased the air voids while demonstrated better flow value and improved the stiffness compared to the conventional HMA. The binder content of the BAHMA increased by $0.6 \%$. The Cecabase RT showed good results in the production of WMA mixtures but did not perform well when used to fabricate BAWMA mixtures.

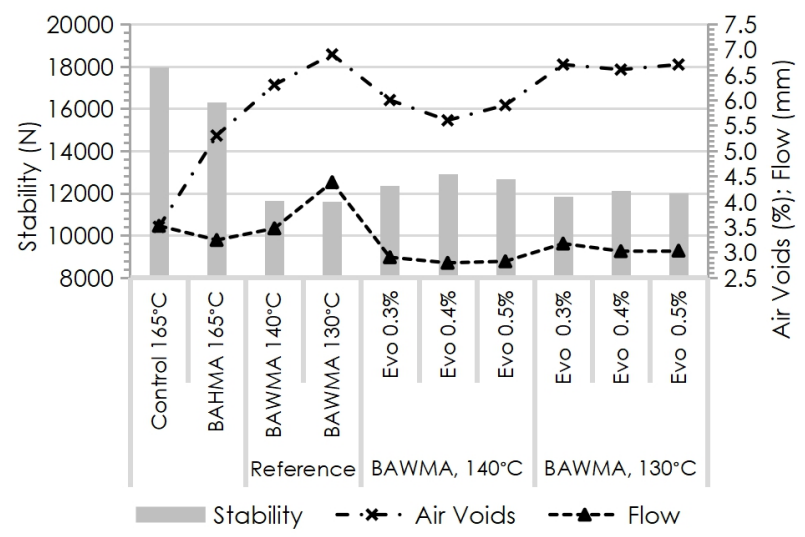

Figure 6 Influence of Evotherm $3 G$ on the stability, air voids and flow of the BAWMA mixtures.

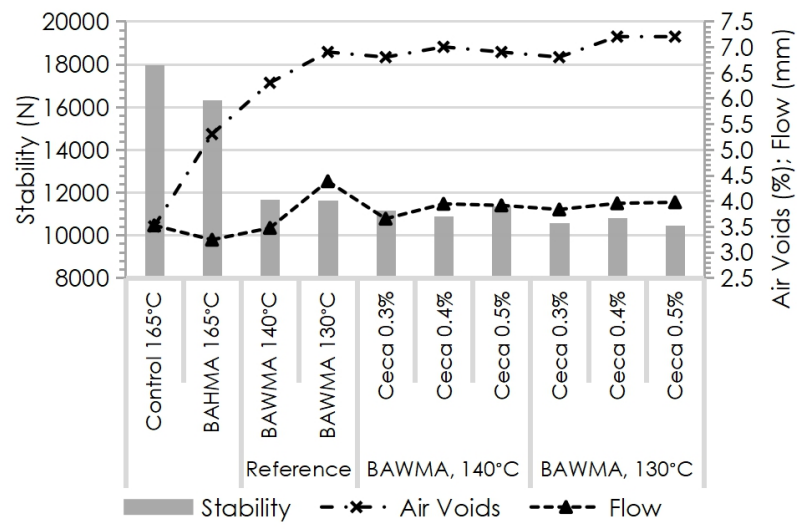

Figure 7 Influence of Cecabase RT on the stability, air voids and flow of the BAWMA mixtures.

The WMA containing $0.3 \%$ Cecabase RT additive showed comparable void contents, specific gravity and flow value to the conventional HMA when produced at $140{ }^{\circ} \mathrm{C}$. However, Evotherm 3G demonstrated a good correlation with WMA and BAWMA mixtures. The WMA and BAWMA at the rate of $0.4 \%$ Evotherm $3 G$ significantly increased the stability and specific gravity compared to the reference WMA and BAWMA. The BAWMA with $0.4 \%$ Evotherm $3 \mathrm{G}$ showed the least flow value and comparable air voids to the BAHMA at the production temperature of $140^{\circ} \mathrm{C}$.
Based on the results achieved from the WMA mixtures mechanical properties, it is concluded that through laboratory investigation, the production temperature could only be reduced by $25^{\circ} \mathrm{C}$ using $0.4 \%$ Evotherm $3 G$.

The studied mechanical properties of BAWMA support the potential utilisation of BA in WMA using Evotherm 3G. However, further research is required to assess both advanced mechanical performance and the environmental impacts of BAWMA.

\section{Acknowledgements}

This work was supported/funded by the Ministry of Higher Education (MOHE) under Fundamental Research Grant Scheme (FRGS) FRGS/1/2019/TK01/UTM/02/6 and the Universiti Teknologi Malaysia for UTMShine grant, Q.J130000.2451.09G26.

\section{References}

[1] Al-Rawashdeh, A. S., Sargand, S. 2014. Performance Assessment of a Warm Asphalt Binder in the Presence of Water by Using Surface Free Energy Concepts and Nanoscale Techniques. J Mater Civ Eng. 26: 803-811. https://doi.org/10.1061/(ASCE)MT.1943-5533.0000866.

[2] Rondón-Quintana, H. A., Fernández-Gómez, W. D. Zafra-Mejía, C. A. 2015. Behavior of a Warm Mix Asphalt using a Chemical Additive to Foam the Asphalt Binder. Rev Fac Ing Univ Antioquia. 129-138. https://doi.org/10.17533/udea.redin.n78al7.

[3] Bonaquist, R. 2011. Mix Design Practices for Warm-Mix Asphalt. (Vol. 691). Transportation Research Board.

[4] Akisetty, C., Xiao, F., Gandhi, T., Amirkhanian, S. 2011. Estimating Correlations between Rheological and Engineering Properties of rubberized Asphalt Concrete Mixtures Containing Warm Mix Asphalt Additive. Constr Build Mater. 25: 950-956. https://doi.org/10.1016/j.conbuildmat.2010.06.087.

[5] Shang, L., Wang, S., Zhang, Y., Zhang, Y. 2011. Pyrolyzed Wax from Recycled Cross-linked Polyethylene as Warm Mix Asphalt (WMA) Additive for SBS Modified Asphalt. Constr Build Mater. 25: 886-891. https://doi.org/10.1016/j.conbuildmat.2010.06.097.

[6] Zeinoddin, H. S., Abtahi, S. M., Hejazi, S. M. et al. 2016. Design and Production of Steel Slag Warm Mix Asphalt (SSWMA) Using an Amino-Based Resin. Transp Infrastruct Geotechnol. 3: 91-108. https://doi.org/10.1007/s40515016-0032-4.

[7] Silva, H. M. R. D., Oliveira, J. R. M., Peralta, J., Zoorob, S. E. 2010. Optimization of Warm Mix Asphalts using Different Blends of Binders and Synthetic Paraffin Wax Contents. Constr Build Mater. 24: 1621-1631. https://doi.org/10.1016/j.conbuildmat.2010.02.030.

[8] Pereira, R., Almeida-Costa, A., Duarte, C., Benta, A. 2018. Warm Mix Asphalt: Chemical Additives' Effects on Bitumen Properties and Limestone Aggregates Mixture Compactibility. Int J Pavement Res Technol. 11: 285-299. https://doi.org/10.1016/j.j.jprt.2017.10.005.

[9] Arega, Z., Bhasin, A. 2012. Binder Rheology and Performance in Warm Mix Asphalt (Part - 2). Report No. 
FHWA/TX-12/0-6591-1, Texas.

[10] James, S. Lai, James, Y. Tsai, Z. W. 2010. Evaluating Constructability and Properties of Warm Mix Asphalt. Report No, FHWA-GA-10-0904, Atlanta, Georgia.

[11] K. R. M., Kumar, N. D., G. S. T. 2014. Performance and Evaluation on Marshall Stability Properties of Warm Mix Asphalt Using Evotherm and Cecabase R+®-A Chemical Additive. Int J Eng Trends Technol. 12: 406-410. https://doi.org/10.14445/22315381/ijett-v12p278.

[12] Ashley Buss, Mohamed Rashwan, R. C. W. 2011. Investigation of Warm-Mix Asphalt Using lowa Aggregates. Report No. IHRB Project TR-599, Ames.

[13] Kheradmand, B., Muniandy, R., Hua, L. T. et al. 2014. An Overview of the Emerging Warm Mix Asphalt Technology. Int J Pavement Eng. 15: 79-94. https://doi.org/10.1080/10298436.2013.839791.

[14] Kuang, Y. 2012. Evaluation of Evotherm as a WMA Technology Compaction and Anti-strip Additive. Thesis (Master's), lowa State University Ames, lowa.

[15] Abd El-Hakim, R. T., Epps, J., Epps Martin, A., ArámbulaMercado, E. 2019. Laboratory and Field Investigation of Moisture Susceptibility of Hot and Warm Mix Asphalts. Int J Pavement Eng. 0: 1-10. https://doi.org/10.1080/10298436.2019.1694150.

[16] Rondón-Quintana, H. A., Ocampo-Terreros, M S., VaccaGámez, H. A. et al. 2016. The Mechanical Behavior of Two Warm-Mix Asphalts. Ing e Investig. 36: 29-38. https://doi.org/10.15446/ing.investig.v36n3.54861.

[17] Yu, X., Leng, Z., Wei, T. 2014. Investigation of the Rheological Modification Mechanism of Warm-Mix Additives on Crumb-Rubber-Modified Asphalt. J Mater Civ Eng. 26: 312-319. https://doi.org/10.1061/(ASCE)MT.1943-5533.0000808.

[18] Liu, Z., Asce, S. M., Yu, X., Asce, M. 2013. Laboratory Evaluation of Warm-Mix Open Graded Friction Course Mixtures. J Mater Civ Eng. 27: 1239-1247. https://doi.org/10.1061/(ASCE)MT.

[19] Fallah Tafti, M., Khabiri, M. M., Khani Sanij, H. 2016. Experimental Investigation of the Effect of using Different Aggregate Types on WMA Mixtures. Int J Pavement Res Technol. 9:

376-386. https://doi.org/10.1016/j.ijprt.2016.09.006.

[20] Omranian, S. R., Hamzah, M. O., Gungat, L., Teh, S. Y. 2018. Evaluation of Asphalt Mixture Behavior Incorporating Warm Mix Additives and Reclaimed Asphalt Pavement. J Traffic Transp Eng. (English Ed 5: 181-196. https://doi.org/10.1016/j.jtte.2017.08.003.

[21] Kusam, A. 2014. Laboratory Evaluation of Workability and Moisture Susceptibility of Warm Mix Asphalt Technologies with Reclaimed Asphalt Pavement Materia. North Carolina State University

[22] Ameri, M., Hesami, S., Goli, H. 2013. Laboratory Evaluation of Warm Mix Asphalt Mixtures Containing Electric Arc Furnace (EAF) Steel Slag. Constr Build Mater. 49: 611-617. https://doi.org/10.1016/j.conbuildmat.2013.08.034.

[23] ecobaccpspec @ www.ecoba.org.

[24] Malaysia EC. 2017. Peninsular Malaysia Electricity Supply Outlook 2017.

[25] Ramz Hannan, N. I. R., Shahidan, S., Ali, N., Maarof, M. Z. 2017. A Comprehensive Review on the Properties of Coal Bottom Ash in Concrete as Sound Absorption Material. MATEC Web Conf. 103: 1-10. https://doi.org/10.1051/matecconf/201710301005.

[26] Plants C of EW-E. 2017. Bottom Ash Fact Sheet. Brussels.

[27] Adams, T. H. 2019. Coal Ash Recycling Rate Declines Amid Shifting Production and Use Patterns. American Coal Ash Association. U.S.A

[28] Ksaibati, K., Rama, S., Sayiri, K. 2006. Utilization of
Wyoming Bottom Ash in Asphalt Mixes. No. MPC Report No. 06-179. Mountain-Plains Consortium.

[29] Ciaran, J. Lynn, Gurmel, S. Ghataora, R. K. D. O. 2016. Municipal Incinerated Bottom Ash (MIBA) Characteristics and Potential for Use in Road Pavements. Int J Pavement Res Technol. 11: 185-201.

[30] Ksaibati, K., Conner, G. L. 2004. Laboratory Evaluation of Bottom Ash Asphalt Mixes. University of Wyoming P.O. Box 3295 Laramie, WY 82071-3295.

[31] Hassan, H. F., Al-Shamsi, K. 2010. Characterisation of Asphalt Mixes Containing MSW Ash using the Dynamic Modulus |E*| Test. Int J Pavement Eng. 11: 575-582. https://doi.org/10.1080/10298436.2010.501865.

[32] Yoo, B. S., Park, D. W., Vo, H. V. 2016. Evaluation of Asphalt Mixture Containing Coal Ash. Transp Res Procedia. 14: 797-803. https://doi.org/10.1016/j.trpro.2016.05.027.

[33] Chen, J-S., Chu, P-Y., Chang, J-E. et al. 2008. Engineering and Environmental Characterization of Municipal Solid Waste Bottom Ash as an Aggregate Substitute Utilized for Asphalt Concrete. J Mater Civ Eng. 20: 432-439. https://doi.org/10.1061/(ASCE)0899-1561 (2008)20:6(432).

[34] Hassan, H. F. 2005. Recycling of Municipal Solid Waste Incinerator Ash in Hot-Mix Asphalt Concrete. Constr Build Mater. 19: 91-98. https://doi.org/10.1016/j.conbuildmat.2004.05.010.

[35] Ramzi, N. I. R., Shahidan, S., Maarof, M. Z., Ali, N. 2016. Physical and Chemical Properties of Coal Bottom Ash (CBA) from Tanjung Bin Power Plant. IOP Conf Ser Mater SCi Eng. 160. https://doi.org/10.1088/1757899X/160/1/012056.

[36] Benson, C. H., Bradshaw, S. 2011. User Guideline for Coal Bottom Ash and Boiler Slag in Green Infrastructure Construction. Recycl Mater Resour Cent. 1: 1-32.

[37] Zhao, S., Huang, B., Shu, X. et al. 2016. Effects of WMA Technologies on Asphalt Binder Blending. J Mater Civ Eng. $\quad 28$ : 04015106. https://doi.org/10.1061/(ASCE)MT.1943-5533.0001381.

[38] Malaysia PWD. 2008. Standard Specification for Road Works, Section 4, Flexible Pavement. Jabatan Kerja Raya Malaysia, Kuala Lumpur.

[39] J. González-León, V. L. 2013. Warm Mix Asphalts with Cecabase RT Additive: Properties And Advantages. 16.

[40] Bennert, T., Reinke, G., Mogawer, W., Mooney, K. 2010. Assessment of Workability and Compactability of Warmmix Asphalt. Transp Res Rec. 36-47. https://doi.org/10.3141/2180-05.

[41] Sol-Sánchez, M., Moreno-Navarro, F., Rubio-Gámez, M. C. 2017. Study of Surfactant Additives for the Manufacture of Warm Mix Asphalt: From Laboratory Design to Asphalt Plant Manufacture. Appl Sci. 7. https://doi.org/10.3390/app7070745.

[42] Ferreira, C., Oliveira, J., Silva, H., Peralta, E. 2009. Evaluation of the Rheological Behaviour of Warm Mix Asphalt (WMA) Modified Binders. Adv Test Charact Bitum Mater. 661-674. https://doi.org/10.1201/9780203092989.ch64.

[43] Vahora, S. I., Mishra, C. B. 2017. Investigating the Performance of Warm Mix Additives. Int J Curr Eng Technol. 7: 1011-1015.

[44] Liu, Z., Wen, J., Wu, S. 2010. Influence of Warm Mix Asphalt Additive on Temperature Susceptibility of Asphalt Binders. 2010 4th Int Conf Bioinforma Biomed Eng ICBBE 2010.2 5-8. https://doi.org/10.1109//CBBE.2010.5516629.

[45] Lu, D. X., Saleh, M. 2016. Laboratory Evaluation of Warm Mix Asphalt Incorporating High RAP Proportion by Using Evotherm and Sylvaroad Additives. Constr Build Mater. 114: 580-587. 
https://doi.org/10.1016/j.conbuildmat.2016.03.200.

[46] Ali Jattak, Z., Abdul Hassan, N., Athma Mohd Shukry, N., et al. 2019. Characterization of Industrial by-products as Asphalt Paving Material. IOP Conf Ser Earth Environ Sci 220. https://doi.org/10.1088/1755-1315/220/1/012012.
[47] Colonna, P., Berloco, N., Ranieri, V., Shuler, S. T. 2012. Application of Bottom Ash for Pavement Binder Course. Procedia - Soc Behav Sci. 53: 962-972. https://doi.org/10.1016/j.sbspro.2012.09.945. 